\title{
Effect of kelp extract on sugarcane plantlets biomass accumulation
}

\author{
Efecto del extracto de algas en la acumulación de biomasa \\ de plántulas de caña de azúcar \\ Luis Claudio Inácio da Silveira ${ }^{1}$, Pedro Mattos ${ }^{1}$, Átila Francisco Mógor ${ }^{1 *}$, \\ Edelclaiton Daros ${ }^{1}$, Marcos de Oliveira Bettini ${ }^{2}$, Jeff Norrie ${ }^{2}$
}

\begin{abstract}
In order to improve the growth of sugarcane plantlets, this study examined the effects of a seaweed (Ascophyllum nodosum) extract on shoot and root dry mass accumulation of plantlets budding from segments taken from apical, medial and basal parts of culms of the RB867515 variety. The experiment was a 3 x 2 factorial (three culm sections x kelp extract applied at 2.01. ha $^{-1}$ and control) at the Sugar Cane Research Station at the Federal University of Paraná, Brazil. Results showed improvement in shoot and root dry mass accumulation in plantlets budding from the basal part of culms following treatment with the A. nodosum kelp extract.

Key words: Ascophyllum nodosum, Saccharum spp., growth.
\end{abstract}

\section{RESUMEN}

Buscando la mejora del crecimiento de las plántulas de caña de azúcar, este estudio inicial examinó los efectos de un extracto de algas (Ascophyllum nodosum) en la acumulación de masa seca de la parte aérea y raíces de plántulas originadas de segmentos tomados de las partes apicales, mediales y basales de la variedad RB867515. El experimento en factorial $3 \times 2$ (segmentos apicales, mediales y basales x extracto de algas aplicada en 2,0 l.ha $a^{-1}$ y control) se llevó a cabo en la Estación de Investigación de Caña de Azúcar de la Universidad Federal de Paraná, Brasil. Los resultados mostraron una mejoría de las acumulaciones de masa seca de los brotes y raíces en las plántulas originadas de segmentos basales por la aplicación de extracto de algas.

Palabras clave: Ascophyllum nodosum, Saccharum spp., crecimiento.

\section{Introduction}

Brazil is the world's largest producer of sugar cane (Saccharum spp.). As one of the most important crops in Brazil, sugar cane production results in a multitude of products such as sugar, ethanol and bagasse (dried fibrous refuse of sugar production) used to produce energy. There is a significant increasing global demand for sugar cane-derived products. As a result, there is a continuing increase in the area under sugar cane production (CONAB, 2012).

Besides adaptations to climate and soil conditions, pests and disease pressures, sugar cane development has also faced new challenges. These new challenges include how to improve the sprouting capacity of plants from under straw cover (due to restrictions on burning of the previous crop litter) to minimize sprout failures. In related studies, Sanguino (1986) emphasized the importance of using good quality cuttings in sugar cane crop establishment, given that the bud source is an important factor in helping minimize sprout failures caused by older buds originating from the basal part of culms. Advances in sugar cane cultivation need to focus on the development of growing techniques that promote budding and faster plantlets growth and establishment.

The commercial extract of Ascophyllum nodosum brown seaweed is a natural product that can stimulate the plant to increase endogenous production of cytokinins (Wally et al., 2013), a class of plant hormones that promote cell division with implications in bud initiation (Taiz \& Zaiger, 2006).

\footnotetext{
1 Federal University of Paraná, Rua dos Funcionários, 1540, Curitiba, Paraná. Brasil. Cep: 8035-050.

2 Acadian Seaplants, 30 Brow Avenue, Dartmouth, Nova Scotia, Canada. B3B 1X. 30

* Corresponding Author: atila.mogor@ufpr.br
}

Fecha de Recepción: 4 Octubre, 2014.

Fecha de Aceptación: 15 Abril, 2015. 
Poly- and oligosaccharides are also frequently found in Ascophyllum nodosum extracts, which may induce different biological activities when applied to plants (Pessatti \& Maraschim, 1998) and stimulate various growth and defense responses. Jenkins et al. (2004) and MacKinnon et al. (2010) detected a number of quaternary ammonium betaines, antioxidant and osmoregulator compounds in Ascophyllum nodosum extracts.

Taking into account the presence of bioactive compounds in A. nodosum commercial extract and beneficial effects of their use reported from different cultivation sites under Brazilian growing conditions (Storck, et al., 2013; Koyama et al., 2012; Silva et al., 2010; Mógor et al., 2008), this study was undertaken to examine the effect of $A$. nodosum extract in biomass accumulation of sugarcane plantlets budding from segments taken from apical, medial and basal parts of culms.

\section{Materials and Methods}

Experiments were initiated on September 2, 2011 at the Sugar Cane Research Station at the Federal University of Paraná (UFPR), latitude $22^{\circ}$ 58 '44.04 S, longitude $27^{\circ} 27$ ” 52.57 ' W. Culms of 10-month old sugarcane (Saccharum spp.) variety RB867515 were collected from the field. The percentage $\mathrm{Brix}^{\circ}$ (total soluble solids) was determined using a field refractometer at basal, medial and apical points of culms to determine their maturation index (IDM = Apical / Basal). The index was determined to be 0.60 , indicating that the sugarcane culms were still immature (green) with little accumulation of sucrose in the stalk. This index reading indicates that the plants were in good condition to be planted.

Culm cuttings were removed from within the $7^{\text {th }}, 15^{\text {th }}$ and $22^{\text {th }}$ internodes measured from base to apex, corresponding respectively to basal, medial and apical parts of culms. From each part, $8 \mathrm{~cm}$ sections containing one bud were separated, thereby providing buds of different physiological ages, the youngest derived from apical sections and the oldest from the basal part of the culm.

The commercial soluble liquid concentrate Ascophyllum nodosum extract (Acadian Seaplants Ltd.) was applied at a rate of 2,0 1.ha- (solution with $0,01 \%$ ) and was compared to an untreated control. The culm parts with one bud were submerged in solution at the aforementioned dosage for 30 minutes.
The control was submerged in distilled water for the same time period.

Culm parts were planted in $2 \mathrm{~L}$ vessels filled with a pine bark substrate $\left(\operatorname{Plant} \operatorname{Max}^{\circledR}\right)$, then placed in the experimental area in randomized complete blocks and $3 \times 2$ factorial design (three culm parts $\mathrm{x}$ kelp extract applied at $2 \mathrm{~L}^{-h^{-1}}$ and control) $^{-}$ with 4 replications. The experiment was closely monitored using controlled irrigation to encourage bud sprouting. Plants were collected at 75 days after planting; shoots and roots were removed, separated and dried in a forced ventilation oven at $65^{\circ} \mathrm{C}$ for 48 hours, then weighed in a precision balance.

Homogeneity of variance was evaluated with Bartlett's test and a mean-square analysis was performed as well as a posteriori comparisons of means using Tukey's test at $\alpha=0.05$. Data were processed using the M-STAT program, version 2.11 (Michigan State University, 1989).

\section{Results and Discussion}

The mean squares analyses, levels of significance, as well as averages and coefficients of variation of shoot and root dry weights are presented in Table 1.

Significant differences were found between shoot and root dry mass taken from the different culm parts (CP). The kelp extract (KE) treatment produced a significant increase in root dry mass accumulation on plantlets that sprout exclusively from basal buds $(\mathrm{p}<0.01)$.

Table 1. Mean square analysis for data of shoot and root dry mass accumulation in plantlets grown from basal, medial and apical parts of sugarcane culms (CP), treated with kelp extract (KE). Sugarcane Experimental Station Paranavaí-PR, Brazil. (UFPR / SCA), 2012.

\begin{tabular}{lcc}
\hline Contrasts & Shoot dry mass $(\mathrm{g})$ & Root dry mass $(\mathrm{g})$ \\
\hline $\mathrm{CP}$ & $56.63^{* *}$ & $4.98^{* *}$ \\
$\mathrm{KE}$ & $2.98^{\mathrm{ns}}$ & $2.41^{* *}$ \\
KE x CP & $12.38^{*}$ & $3.50^{* *}$ \\
KE x CP Basal & $23.19^{* *}$ & $8.69^{* *}$ \\
KE x CP Medial & $0.08^{\mathrm{ns}}$ & $0.20^{\mathrm{ns}}$ \\
KE x CP Apical & $4.47^{* *}$ & $0.51^{\mathrm{ns}}$ \\
Error (18 DF) & 3.20 & 0.50 \\
CV\% & 28.91 & 26.56 \\
\hline
\end{tabular}

$* \mathrm{P}<0.05$ is significant at the $5 \%$ probability $\mathrm{F}$. $* * \mathrm{P}<0.01$ is significant at $1 \%$ probability, and ${ }^{\mathrm{ns}}$ not significant. DF degrees of freedom $\mathrm{CV} \%$ coefficient of variation. 
Table 2. Average values ( $\mathrm{g}$ ) of shoot and root dry mass (Sdm, Rdm, respectively) of plantlets grown from basal, medial and apical parts of sugarcane culms (CP), under kelp extract (KE) treatments, and control. Sugarcane Experimental Station, Paranavaí-PR, Brazil. (UFPR / SCA), 2012.

\begin{tabular}{lcccccc}
\hline & \multicolumn{7}{c}{ Culm parts (CP) } \\
\cline { 2 - 7 } & \multicolumn{2}{c}{ Apical } & \multicolumn{2}{c}{ Medial } & \multicolumn{2}{c}{ Basal } \\
\cline { 2 - 7 } & Sdm & Rdm & Sdm & Rdm & Rdm \\
\hline KE & $7.54 \mathrm{a}$ & $3.58 \mathrm{a}$ & $6.97 \mathrm{a}$ & $3.06 \mathrm{a}$ & $5.10 \mathrm{a}$ & $2.84 \mathrm{a}$ \\
Control & $9.04 \mathrm{a}$ & $3.07 \mathrm{a}$ & $6.76 \mathrm{a}$ & $2.74 \mathrm{a}$ & $1.70 \mathrm{~b}$ & $0.76 \mathrm{~b}$ \\
Mean & 8.29 & 3.33 & 6.86 & 2.90 & 1.80 & 1.80 \\
\hline
\end{tabular}

The results presented in Table 2 show the growth-promoting effect of KE due to greater dry matter production from the basal $\mathrm{CP}(\mathrm{P}<0.05)$. Basal buds, being physiologically older, had lower amounts of reducing sugars (glucose and fructose), lower nitrogen reserves, and a lower concentration of plant growth hormones, with special attention given to cytokinins (Otto et al., 2009).

Dry matter accumulation in sugarcane plantlets related to KE treatments of older buds, may be an important step in developing a sustainable technology to help minimize sprout failures and improve the initial growth of sugarcane plants.

\section{Literature Cited}

CONAB. Companhia Nacional de Abastecimento.

2012. Central de informações agropecuárias: safras-cana.

Disponíble en: www.conab.gov.br Consultado: 01/02/2012.

Jenkins, S.R.; Norton, T.A.; Hawkins, S.J.

2004. Long term effects of Ascophyllum nodosum canopy removal on mid shore community structure. Journal of the Marine Biological Ass. U.K., 84:327-329.

Koyama, R.; Bettoni, M.M.; Röder, C.; Assis, A. M.; Roberto,

S. R.; Mógor, A.F.

2012. Extrato da alga Ascophyllum nodosum (L.) Le Jolis, no desenvolvimento vegetativo e na produção do tomateiro. Revista de Ciências Agrárias, 55: 282-287.

MacKinnon, S.L.; Hiltz, D.; Ugarte, R.; Craft, C.A.

2010. Improved methods of analysis for betaines in Ascophyllum nodosum and its commercial seaweed extracts. Journal of Applied Phycology, 22 (4): 489-494.

Mógor, A.F.; Ono, E.O.; Rodrigues, J.D.; Mógor, G. 2008. Aplicação foliar de extrato de alga, ácido L-glutâmico e cálcio em feijoeiro. Scientia Agraria, 9: 431-437.

Otto, R., Franco, H.C.J.; Eduardo, C.; Vitti, A.C.; Trivelin, P.C.O. 2009. Fitomassa de raízes e da parte aérea da cana-de-açúcar relacionada à adubação nitrogenada de plantio. Pesquisa Agropecuária Brasileira, 44 (4): 398-405.

Pessatti, M.L.; Maraschin, M.

1998. Atividades biológicas e aspectos estruturais de carboidratos de origem marinha. In: Jornada Catarinense de Plantas Medicinais - saúde e sustentabilidade para o $3^{\circ}$ Milênio. Anais. Tubarão: Unisul, 47-51, 183 p.

Sanguino, A.

1986. Como formar viveiros de mudas de cana-de-açúcar. In:

Seminário de Tecnologia Agronômica, 3. Anais. Piracicaba: ESALQ/USP, 229-242.

Silva, C.P.; Laschi, D. ; Ono, E.O.; Rodrigues, J.D.; Mógor, A.F. 2010. Aplicação foliar do extrato da alga Ascophyllum nodosum e do ácido glutâmico no desenvolvimento inicial de crisântemos (Dendranthema morifolium (Ramat.) Kitam.) em vasos. Revista Brasileira de Horticultura Ornamental, 16: 179-182.

Stork, R.C.; Deschamps, C. ; Mógor, A.F.; Coccô, L.C. ; Scheer, A.P.; Yamamoto, C.I.

2013. Desenvolvimento vegetativo e produção de óleo essencial de patchouli (Pogostemon cablin (Blanco) Benth.) após a aplicação de ácido giberélico e extrato de alga marinha. Revista Brasileira de Plantas Medicinais, 15: 391-396.

Taiz, L.; Zeiger, E. 2006. Fisiologia Vegetal, 3. Porto Alegre: Artmed. 722 p. Wally, O.S.D.; Critchley, A.T.; Hiltz, D.; Craigie, J.S.; Han, X.; Zaharia, L.I.; Abrams, S.R.; Prithivira, B.

2013. Regulation of phytohormone biosynthesis and accumulation in Arabidopsis following treatment with commercial extract from the marine macroalga Ascophyllum nodosum. Journal of Plant Growth Regulations, 32:324-339. 
